Çukurova Üniversitesi Eğitim Fakültesi Dergisi

Vol: 50 Numb: 2 Page: 677-697

https://dergipark.org.tr/tr/pub/cuefd

\title{
An Evaluation on Habitus in Visual Arts Education
}

\author{
Ece Nur DEMIR YILMAZ ${ }^{\mathrm{a}^{*}}$ (ORCID ID - 0000-0003-0240-1804) \\ Alev ÇAKMAKOĞLU KURU ${ }^{b}$ (ORCID ID - 0000-0002-0002-3160) \\ ${ }^{a} A$ ksaray Üniversitesi, Eğitim Fakültesi, Aksaray/Türkiye \\ ${ }^{b}$ Gazi Üniversitesi, Gazi Eğitim Fakültesi, Ankara/Türkiye
}

\section{Article Info}

DOI: $10.14812 /$ cufej.947600

Article history:

Received 03.06.21

Revised $\quad 31.08 .21$

Accepted $\quad 08.10 .21$

Keywords:

Habitus,

Cultural Capital,

Art,

Visual Arts Education,

Sociology of Art.

\begin{abstract}
It is necessary to consider an examination that causes our interests, attitudes and behaviors towards art and makes the creation and consumption of art meaningful and understandable from different perspectives. The interaction between the elements of social structure and art is one of the areas that can be addressed in this sense. This situation requires a shift to a sociological point of view because it contains theoretical bases that will enable the examination. One of the theoretical structures that will enable a sociological examination is Pierre Bourdieu's concept of habitus. The concept of habitus represents our habits, tendencies, appreciations, etc. While thinking about our artistic tendencies, appreciations, behaviors and predispositions, the role and decisiveness of habitus emerge as an approach that we can use in theory. This study aims to try to explain the concept of habitus, which is mentioned with sociologist Pierre Bourdieu, in the context of Visual Arts Education. The research was created based on the literature review. Within the scope of the literature, the theoretical foundations of the concept of habitus have been explained and summarized, and the basic characteristics of habitus have been interpreted through art and visual arts education. Based on the findings of the research, the concept of habitus has emerged as a theoretical approach that will help art education researchers to make sense of artistic and educational behaviors and encourage them to think deeper about the subject.
\end{abstract}

\section{Resim-Iş (Görsel Sanatlar) Eğitiminde Habitus Üzerine Bir Değerlendirme}

Makale Bilgisi Öz

DOI: $10.14812 /$ cufej.947600

Makale Geçmişi:

Geliş 03.06.21

Düzeltme $\quad 31.08 .21$

Kabul $\quad 08.10 .21$

Anahtar Kelimeler:

Habitus,

Kültürel Sermaye,

Sanat,

Görsel Sanatlar Eğitimi,

Sanat Sosyolojisi.
Sanata karşı ilgi, tutum ve davranışlarımıza kaynaklık eden; sanatın üretim ve tüketimini anlamlı ve anlaşılır kılan bir incelemeyi farklı açılardan ele almak gerekmektedir. Toplumsal yapının ögeleri ile sanatın etkileşimi bu anlamda ele alınabilecek alanlardan birisidir. Bu durum, incelemeyi olanaklı kılacak kuramsal dayanaklar içermesi sebebiyle sosyolojik bakışa yönelmeyi gerektirmektedir. Sosyolojik anlamda bir bakışı mümkün kılacak kuramsal yapılardan birisi Pierre Bourdieu'nün habitus kavramıdır. Habitus, anlamı itibariyle alışkanlıklarımızı, eğilimlerimizi, beğenilerimizi vb. temsil etmektedir. Sanatsal eğilimlerimiz, beğenilerimiz, davranışlarımız ve yatkınlıklarımız üzerine düşünürken habitusun rolü ve belirleyiciliği, teoride kullanabileceğimiz bir yaklaşım olarak karşımıza çıkmaktadır. Bu çalışmanın amacı, Sosyolog Pierre Bourdieu ile anılan habitus kavramını görsel sanatlar eğitimi bağlamında açıklamaya çalışmaktır. Araştırma literatür taramasına dayalı olarak oluşturulmuştur. Literatür kapsamında habitus kavramının kuramsal temelleri açıklanmış ve özetlenmiş; habitusun temel özellikleri sanat ve görsel sanatlar eğitimi üzerinden yorumlanmıştır. Araştırma bulgularına dayalı olarak habitus kavramı, sanatsal ve eğitsel davranışları anlamlandırmada sanat eğitimi araştırmacılarına yardımcı olacak ve konu üzerine daha derin düşünmeye teşvik edecek teorik bir yaklaşım olarak karşımıza çıkmıştır. 


\section{Introduction}

Artistic predispositions are shaped by artistic experiences. Since the birth of the person, all his/her experiences related to art give him/her a certain perceptual feature in art. The artistic perception gained through experiences creates a consciousness that guides the attitudes and behaviors related to art such as artistic production, artistic appreciation, and artistic consumption. Resources supporting the creation of this consciousness can be subject to various disciplines, especially psychology. One of these disciplines is the sociology of art. Pierre Bourdieu, who stands out with his works on the artistic appreciation, artistic production, and consumption in art sociology, presented a theoretical tool that allows us to conduct a sociological examination of artistic predispositions with the concept of habitus he developed. It is thought that the use of habitus as a guiding concept in explaining artistic predispositions and differentiating orientations in aesthetic judgments will contribute to the education of visual arts by examining its determinants in relations established with art along with the level of education and artistic experiences.

It is known that the concepts of capital and field are among the other concepts that Bourdieu has developed outside the habitus and brought to the literature. Since these concepts gain meaning concerning each other, they constitute important theoretical structures discussed in the research. There are differences in terms of capital (economic, cultural, social, and symbolic capital) and habitus definition, but these concepts act together and affect each other. The field is another important part that covers this interaction. Therefore, when talking about habitus, it becomes meaningful to address these concepts together, considering the effect of field and capital on habitus.

Since the research includes an evaluation of the relationship between education, art, and sociology, the concept of cultural capital, one of the capital types of Bourdieu, accompanies the habitus. Cultural capital means the level of education an individual has (Danko, 2017, p. 64). Bourdieu's "[concept of] cultural capital concerns forms of cultural knowledge, competences or dispositions" (Johnson, 1993, p. 7). ". . . it means information that will decipher and benefit from the relevant codes of artworks when considered in the context of art. .." (Danko, 2017, p. 64). Cultural capital is a concept that has been the subject of study in educational sociology and art sociology. While the concept of cultural capital in educational sociology makes it possible to examine subjects such as students' relationship with academic achievement/school success (DiMaggio, 1982); within the scope of art sociology, it is seen that this concept is addressed in terms of shaping the interests, attitudes, and behaviors of individuals towards art, such as cultural experiences acquired through family and education, having cultural products, education level, etc. (Bourdieu, 2015; Bourdieu \& Darbel, 2011; Sankır \& Sankır, 2019; Swartz, 2018). Accordingly, the effect of cultural capital gained through family and school on directing the behaviors of individuals in educational and artistic terms is more prominent than other types of capital while thinking about habitus.

The influence of family and school on cultural capital is responded to by the formation of the habitus and the reactions to art. Tezcan (2016) stated that the habitus' formed by the process of school include the combination of knowledge, intellectual style, attitude, behavior, and language. Considering the role of teachers in this process, the topic of teacher training comes to the forefront. Practices and experiences within the school climate and curriculum/program structure of universities during the teacher training process create a culture for the perception of the teaching profession. It is thought that habitus is an important tool to discover the effects of this culture on training a qualified teacher. In this context, teacher training, practices in the teaching process, and the relationship with habitus are the issues that need to be considered. Because the habitus gained through education will continue to multiply and reproduce itself. At the same time, education can be expressed as one of the social institutions that have important roles in the formation of artistic consciousness, the formation and development of artistic appreciations, and the determination of the positions of individuals in the field of art. It is needed to discover the contributions of the education process to artistic production and consumption by associating it with habitus. As Fazlıoğlu Akın and Ece (2014) stated, "policies of art education are very important for the development and growth of a country's creative and cultural 
DEMIR YILMAZ \& ÇAKMAKOĞLU KURU - Çukurova Üniversitesi Eğitim Fakültesi Dergisi, 50(2), 2021, 677-697

capital" (p. 19). For this reason, it is necessary to understand the importance of training teachers in the field of visual arts on the axis of the concept of habitus and to draw attention to the importance of visual arts education in sociological terms.

This research aims to present a general framework on the concept of habitus and to raise the importance of inquiries and discoveries about artistic habitus. In this direction, the research deals with the habitus in terms of visual arts education. It is important to think about the habitus through visual arts education in terms of developing a theoretical perspective against the conditions that direct the positioning of education, which has a share in the acquisition of cultural capital, in particular visual arts education, in the field of art and its role in structuring the artistic habitus of the individual. To understand and define the relationship of the individuals with art, their participation in art, and their pedagogical activities, it is thought that it is valuable to produce a sociological narrative in the name of visual arts education by evaluating the role of art education in theory and practice over the meaning that Bourdieu attributes to the concept of habitus.

\section{Method}

This research, in which a general evaluation is made about the concept of habitus in visual arts education, is a review article. The data were collected through a literature review. "Literature review is a systematic process carried out to find, evaluate and synthesize the information produced by other thinkers, researchers and practitioners on the subject under investigation and to learn the current situation" (Booth, Papaionnou and Sutton, as cited in Karasar, 2017, p. 94). Pautasso (2013) used 10 basic rules in his study to reflect the data obtained from the literature review. The basic rules recommended in literature review writing are as follows:

1. Define a topic and audience,

2. Search and re-search the literature,

3. Take notes while reading,

4. Choose the type of review you wish to write,

5. Keep the review focused, but make it of broad interest,

6. Be critical and consistent,

7. Find a logical structure,

8. Make use of feedback,

9. Include your own relevant research, but be objective,

10. Be up-to-date, but do not forget older studies (Pautasso, 2013).

In line with the above-mentioned articles, the studies in the literature on the subject have been investigated and pioneering and current studies have been examined. In the light of the literature, the theoretical foundations of the concept of habitus have been explained and summarized; the basic features of habitus have been interpreted through art and visual arts education. Two experts were consulted in classifying and configuration the theoretical structure of the study. The theoretical structure including evaluation on habitus in visual arts education is presented under three basic topics.

\section{Findings}

\section{The Concept of Habitus}

The concept of habitus is one of the important theoretical concepts of the French sociologist Pierre Bourdieu. As a result of the literature review and in the focus of the information we encounter, it is necessary to examine the starting point and definition of the concept of Habitus, what it corresponds to, and what it sources from; Jourdain and Naulin state that the concept of habitus emerged after Saint Thomas d'Aquin translated the concept of Aristotle's Hexis and Bourdieu reinterpreted the concept. According to Bourdieu in this study, habitus is defined as:

Consists of the templates of comprehension (about how the world will be perceived), evaluate (about how to evaluate) and action (about how to behave) that individuals have more or less 
unconsciously internalized and adopted during the time they socialize - primary education in childhood and secondary education in adulthood- (Jourdain \& Naulin, 2016, p. 42).

In his study, Danko (2017) states that Bourdieu took the concept of habitus from Erwin Panofsky and defines habitus as "a system of internal tendencies; thoughts, perceptions and action schemes gained through socialization" (p. 59). Swartz (2018) stated in his study that Erwin Panofsky's ideas helped Bourdieu to form the concept of habitus. The opinions that will form the basis of these sources, which express ideas on Bourdieu's works and ideas, are included in Bourdieu's The Rules of Art. On the foundations of the concept of Habitus, Bourdieu stated that he benefited from Panofsky's two articles published in French and reinterpreted the transformation of the concept of Aristotelian Hexis into habitus and the use of the concept of habitus (Bourdieu, 2020, pp. 313-314).

In another source, habitus can be explained as ". . . which can be described as the learned dispositions such as bodily comportment, ways of speaking or ways of thinking and acting which are adopted by people in relation to the social conditions in which they exist and move through" (Giddens \& Sutton, 2016, p. 901). Thinking about Bourdieu's works, Swartz (2018) expressed the habitus as follows:

Bourdieu has also used the wording "cultural unconscious," "habit-forming force," "set of basic, deeply interiorized master-patterns," "mental habit," "mental and corporeal schemata of perceptions, appreciations, and action," to designate his key concept. The concept has broadened in scope over time to stress the bodily as well as cognitive basis of action and to emphasize inventive as well as habituated forms of action (pp. 144-145).

Based on Bourdieu's thoughts on habitus, the influence of many people such as Aristotle, Saint Thomas d 'Aquin, Emile Durkheim, Norbert Elias, Marcel Mauss, Max Weber is mentioned (Jourdain \& Naulin, 2016, p. 42). In the studies conducted on Bourdieu within the scope of the research, the meanings attributed to the habitus appear to be similar. In general, the concept refers to our thoughts, behaviors, tendencies, and predispositions. It is seen that the habitus, which is one of the sociological subjects, is fundamentally nourished by psychology. It can be expressed that it is present under the influence of social conditions in the axis of cognitive structure.

An important point about habitus is that it is both structured and constructive (Swartz, 2018, p. 148). Habitus is both produced by individuals and also affects individuals. Hardy (2009) mentions in his study that the habitat is not measured directly, that produced individually and collectively, that is valuable to analyze within a certain geographical and temporal context, that is born from the combination of different types of capital, that operates interactively with the field, that may vary in terms of some variables (age, social status, family origin, etc.), that may transform, change and develop over time, and some features are remarkable. Starting from this point, if it is desired to investigate exploring the habitus, these features should be taken into consideration.

Habitus makes some data about the individual explanatory in terms of the meaning it contains. It is thought that the meaning of habitus is important for the evaluations to be made on art and art education.

\section{Habitus and Art: Artistic Habitus}

Mentioning a single definition of art and limiting the definition of art will not make much sense, especially today. The meanings attributed to art are expanding in terms of those who follow and produce art. Since humanity has existed and art has been described as art, methods of producing art, participating in art, and making sense of art have multiplied. The scope of artistic productions of different cultures in different historical periods has also multiplied some evaluations. The nature of talking about art, understanding art, or producing art causes a situation such as the differentiation of artistic tendencies/preferences. The problem of finding a common ground is tried to be explained with concepts such as aesthetic appreciation, aesthetic pleasure, and aesthetic preference. The concepts from different disciplines can provide a perspective that will help these explanations and support the terminology of art within itself. At this point, it is thought that thinking about the concept of habitus 
through art will be a guide in terms of making a sociological analysis of art, forming ideas about the causes of artistic approaches or tendencies, and making sense of artistic behaviors.

First of all, it is necessary to think about habitus as one of the important theoretical foundations in the analysis of artist identity. Habitus shows a feature that affects the formation and continuity of artist identity. Habitus plays an active role in the formation of artist identity under the influence of individual characteristics and social conditions. The relationships that the individual experiences latent or directly through his/her family and education in his/her life, whether consciously or unawares, with art should be considered as a part of the formation of artistic identity. Habitus, which is shaped in the surrounding of life, reveals the state of having knowledge and culture that can be effective in the topic such as artistic thinking schemes, ways of producing art, determining artistic language, artistic choices, participation in artistic activities, etc. The patterns that the individual internalizes about art will create his/her artistic identity, and art will reveal itself in forms of production and consumption. For this reason, habitus has an important function in the formation and definition of artist identity.

Another issue that needs to be emphasized regarding habitus is that it can change and transform over time. When the individual's art knowledge, in another word, his/her cultural capital is supported by other types of capital, there may be developments and changes in his/her habitus. If we consider this situation in the context of art, which Jourdain and Naulin (2016) state as "habitus varies according to the living conditions and the social path followed by everyone" (p. 43), the dynamic and ever-expanding structure of art, as well as the change of habitus and capital from person to person, means that the artistic habitus can change. Even the increase of one's capital may mean a change in one's habitus (Biçer Olgun, 2019, p. 54).

It is necessary to think about the emergence and reception of art creations, compositions, or works through the concept of habitus. It is known that an individual's artistic experiences and aesthetic appreciation have reflections on the production process and have concretely turned into art products. At this point, it can be stated that the habitus owned by the individual who produces art creations, compositions, or works has a shaping role and effects on the structural or intellectual characteristics of the art object. In this context, it is possible to consider the art object as an important part of the habitus. Bourdieu shows us with his thoughts on the effect of the artistic production field on the emergence of art creations.

Bourdieu summarizes: "so the subject of the work is the habitus and place where this habitus is located, in other words, a field [...]". Social determinisms in which the artwork carries traces affected by the habitus owned by the producer and influence, and send it to the social conditions in its production: they send it as a social subject (family, etc.), as a producer (school, professional contacts, etc.). Social determinisms are also affected by demands and social pressures shaped by the position held by the art producer in a certain production area (to a certain extent in an autonomous area). The phenomenon we call "creation of work" is the combination of a socially established habitus and a cultural production work in the social division of labor or a possible position [...].

Thus, the subject of the work of art is neither an original artist (the artist is the apparent cause) nor a social group [...]. The subject is the artistic field of production as a whole [...] (Bourdieu, as cited in Heinich, 2013, p. 102).

With the expressions given here, Heinich (2013) drew attention to the evaluation of the source of artistic production as a whole. In another source, the degree of relationship between the art field and habitus in art production is stated as follows:

The sociology of cultural works must take as its object the totality of relations (objective ones and also those effectuated in the form of interactions) between the artist and other artists, and beyond them, the totality of actors engaged in the production of the work or, at least, of the social value of the work (critics, gallery directors, patrons, etc.). . . What people call 'creation' is the conjunction of socially constituted habitus and a certain position (status), either already 
constituted or possible in the division of labor of cultural production (and, moreover, at a second degree), in the division of labor of domination (Bourdieu, as cited in Zolberg, 2013, p. 130).

This situation shows the functioning of the habitus in the emergence of the artist and the work of art. Heinich (2013), who is known for his studies on art sociology, stated that ". . what makes it possible to judge the quality of a photograph, or to find a way in a museum, is the "order of these abilities" that are internalized in actors, that is, the habitus" (p. 65). As can be understood from the statements of Heinich (2013), in the context of art, habitus corresponds to an internal order that guides our behavior as an art producer, audience, and receptive. An area is required to reveal this order. The concept that Bourdieu refers to as 'field' corresponds to this area. Giddens and Sutton (2016) define Bourdieu's concept of the field as ". . .various social spaces or arenas where competitive struggles take place" ( $p$. 901). Interacting with the field is an important feature for exploring the habitus. The subject of the field should be considered in the context of the field of art. On the field of art, Bourdieu (2020) stated:

... the definition of the meaning and value of the work of art by living by art and living for art, in short, by connecting all art producers classified as artistic, large or small, famous, in other words, glorified or unrecognized, critics, collectors, intermediaries, museum managers who constitute an area themselves, therefore, involves everyone who opposes each other in competition conflicts to determine the boundaries of the art and (real) artist world and contributes to the production of the art and artist's value through these conflicts (p. 501).

In Bourdieu's The Field of Cultural Production: Essays on Art and Literature, it is seen that in addition to the direct producer of a work, teachers and families who contribute to the meaning and value of the work and produce consumers who can know and recognize the work of art are also included in the field (Bourdieu, 1993, p. 37). Accordingly, Bourdieu's concept of the field as a source of how the creative process is shaped shows a characteristic as a complement to the concepts of capitals and habitus.

For example, in the field of art and aesthetics, cultural capital is most highly prized and those who are able to converse knowledgeably about the history of art or music and so on become powerful within the field - hence the power of the critics in literature or cinema to make or break a book or film with their reviews, for example (Giddens \& Sutton, 2016, p. 901).

Again, when we think about reading and making sense of a work of art or read what is generally visual in the context of visual culture, Schirato and Webb's (2004) statements such as "reading, we argue, is both an active and a creative process; and when reading the visual, we draw on our general and specific knowledges, our tastes and habits and our personal contexts (what Pierre Bourdieu calls the habitus) to make what we see, and to make sense of it" (pp. 6-7) allow us to think about the connections of habitus with art. When we analyze a work or question the images of visual culture, the orientation of our knowledge and experiences results in our reactions within our habitus. Webb, Schirato, and Danaher (2002) define habitus as:

A concept that expresses, on the one hand, the way in which individuals 'become themselves'-develop attitudes and dispositions-and, on the other hand, the ways in which those individuals engage in practices. An artistic habitus, for example, disposes the individual artist to certain activities and perspectives that express the culturally and historically constituted values of the artistic field (pp. xii-xiii).

Danko (2017) stated that ". . social position and habitus play an important role in what people will perform and how they will benefit from it" (p. 59). With these views, the power that affects artistic production/creation and reception and mobilizes the individual internally and externally can be evaluated in the context of habitus. In this sense, habitus plays an effective role in directing and explaining the art-related behaviors of the individual.

An important point to consider when thinking about habitus is time and context. Evaluation of aesthetic preferences of a certain group in a given period within its own period will make the 
DEMIR YILMAZ \& ÇAKMAKOĞLU KURU - Çukurova Üniversitesi Eğitim Fakültesi Dergisi, 50(2), 2021, 677-697

sociological analysis of art in terms of production and reception/consumption forms meaningful. This situation leads us to evaluate the habitus in the context of time and space. An example of the evaluation of habitus in the context of time and space on a framed sample was discussed in the studies of Hardy and Grenfell (2006). Based on Bourdieu's theoretical perspective, the study shows an artistic and biographical examination feature and offers exploratory analyses of the formation of avant-garde artists on the axis of artists' social, economic, cultural capital, and art field. Here, a biographical approach was used in the discovery of the artist's habitus to obtain data about the artist. Biographical researches are used to explain their relationship with the social structure by focusing on the experiences of the subjects (Güvercin, 2017). Gaining an idea about how artists in the field obtain their positions through artistic and biographical analysis is a remarkable study because it includes indicators of the field of cultural production.

One of the important things about art is talent. The discovery of artistic talent takes place under the influence of appropriate conditions. If the development of the discovered artistic talent is supported, the life of the individual can be integrated with art. The family is the first environment in which the discovery of artistic talent is revealed. The family, which has an important place in the discovery of talent, also creates an environment of interest in art, artistic appreciation, and more interest in art. Erinç (2009) stated that in addition to the genetic characteristics of talent, another important factors are the attitudes and behaviors of the family. It is stated that families who support artistic activities are mostly families who are interested in art and have art knowledge (Ulusoy, 2005, p. 143). This situation becomes more meaningful with the role of the family in orienting towards an artistic profession. Because the family's interest in art and the value it attaches to art will be transferred to the child (Tezcan, 2011, p. 81). In line with the statements made here, the transferability of the habitus makes the role of the family valuable in the formation of the habitus in terms of art. It is necessary to draw attention to the impact of one's capital and habitus in the process of the formation of talent and becoming an artist. Since the development of the individual in social dynamics, in another word, the habitus makes it possible to analyze how he/she develops an approach to art with what connections, opportunities, and accumulations in the formation of the artist identity and how he/she gains recognition in the field of art, an examination on the artist person will set an example for the individuals who want to be artists and will be a guide. A comprehensive perspective on the subject is included in the study of Grenfell and Hardy (2003). In the study, the relationship between the field of art and habitus was examined in the sample of contemporary British artists. The processes and functioning of avant-garde art are discussed in the context of Bourdieu's theory. An example for the examination in the context of Turkey can be given by the work of Biçer Olgun (2019). In his work with 25 participants, 9 of whom are curators and 16 are artists in the field of visual arts, Biçer Olgun (2019) examined how the identity of an artist is built, what the work of art is, how it gains value and through which social actors it is produced socially, and how the value of the work of art is built socially. The theoretical foundations of this study also include Bourdieu's capital, habitus, and field concepts. Again, in this study, attention was drawn to the power of habitus and capital in the field of art. Since it will provide a road map that will help individuals who want to progress in this way, it is thought that the studies to be carried out on the field of art and artist habitus are important.

It is necessary to talk about the role of habitus on our artistic appreciations and preferences. Along with the changes and transformations in art, the orientations about the formation and development of artistic value judgments are also diversifying. It can cause differentiation in artistic appreciation and evaluation of works of art. Many elements can provide a basis for this issue. Factors such as the characteristics of the individual's living space, cultural life, family structure, gender, education, age, etc. can affect the appreciation. Bourdieu's work Distinction has an important place in the relation of art appreciation and habitus. In his study, Bourdieu took a class approach to the subject and addressed his inquiries about art and appreciation in this context (Bourdieu, 2015). Over time, different perspectives on artistic preferences or appreciations have become a current issue. The exhibition titled A Question of Taste, which is a recent exhibition and took place in the Pera Museum is a remarkable example of the subject (see Pera Müzesi, n.d.). In addition to the approach that appreciation is related to the class, the 
DEMIR YILMAZ \& ÇAKMAKOĞLU KURU - Çukurova Üniversitesi Eğitim Fakültesi Dergisi, 50(2), 2021, 677-697

exhibition in Turkey questions the sources that feed the appreciation in the context of visual culture, kitsch, and digital culture. An important point to be addressed about artistic appreciation is the concepts of cultural omnivorousness, cultural expansion, and meltdown scenario (Karademir Hazır \& Purhonen, 2017). These concepts point to the extension of the definition of art, participation in art and appreciations, and the elasticising of hierarchical order and classifications between cultural elements or genres (Karademir Hazır \& Purhonen, 2017; Karademir Hazır \& Warde, 2016). At the same time, the effect of mass media in accessibility/attainability to art, the dominance of visual culture, mass culture, and globalization-based situations have expanded the paths of artistic experience. This feature of artistic creation and experience emerges as a situation that also affects artistic appreciation.

One of the elements of the social structure that affects and shapes the habitus is education. In the general education system, art education emerges as decisive expertise in the support of artistic habitus and directing our movements within the field of art. Under this title, while the subject of artistic habitus is emphasized in terms of developing a theoretical perspective against the factors that affect the artist identity and positioning in the field of art, it will be meaningful to think about the habitus in art education, the role of education -visual arts education, in particular- in constructing the artistic habitus, pedagogical activities in art education, and to evaluate the function of art education/educator in theory and practice in the next title.

\section{Visual Arts Education and Habitus}

Educational institutions are one of the structures that create of the art field such as artists, art critics, curators, gallery owners, producers, and marketers of art materials, etc. In this sense, visual arts education emerges as one of the dynamics of the art field. For this reason, the role of education in the evaluation of the concept of habitus is one of the important points to be addressed. In the context of the field of art, the degree and quality of art education have the features to affect the dynamics of the field. It is necessary to think about the role of the individual's education in participation in the field of art and its struggle in the field. The fact that the education process is a process that affects the habitus, that the education related to art shapes the artistic habitus, and that it appears as one of the dimensions that will guide our movements in the field of art makes the role of teachers in the field of art valuable. It is necessary to draw attention to the duties and responsibilities of art education and the function of teachers (art educators) to shape artistic habitus.

The cultural capital accumulation and consequently the formation of the habitus of the individual, who performs his/her first learning experiences with the family, continues after being involved in the school process. When this situation is considered in a certain field-oriented, -which we think in the art field-oriented-it will guide the attitudes and tendencies of the individual. The effect of the individual's capital and habitus in the progress and struggle in the field of art acts as a whole. Education is one of the social institutions that source this movement. The habitus created by education through school should be evaluated in the context of visual arts education in terms of art.

Thinking about the attitudes and preferences of individuals who have received art education towards the artistic and aesthetic is considered important in the context of the predictions that these attitudes and preferences will reveal pedagogically. The aesthetic preferences of an individual who is doing his/her duty as a visual arts teacher will be revealed in the selection of pedagogical content. Art knowledge (Art History, Art Philosophy, Art Criticism, and other art sciences) has an important place in the construction of intellectual consciousness. ". . . that understanding a work of art depends, in its intensity, modality, and even its existence, on the viewer's mastery of the generic and specific code of the work (in other words, on his or her artistic competence), and that it derives partly from learning at school. .." (Bourdieu \& Darbel, 2011, p. 92). For example, the selection, presentation, and transfer of visuals in Art History courses include the pedagogical approach that shapes our schemas of thinking, understanding and evaluation of art. The effect of this approach on cultural capital and thus its effect on habitus will be manifested itself in the reactions, resistances, and attitudes towards art. Along with the movements or trends in Art History, information about artworks is presented. The information presented contributes to the cultural capital gained through education. This contribution, therefore, 
affects the habitus of the individual. It will affect both artistic practices and pedagogical activities in terms of art production. Habitus will serve as the determinant of artistic visuals and activities that will take place in the learning-teaching process.

Artistic knowledge is transferred to students during the teaching profession with each teacher candidate and contributes to the construction of artistic attitudes and preferences. This is the habitus that is formed through education in the school environment. This situation will play a role in the power that will affect the habitus of other individuals. Transfers and experiences that will take place through education will serve as a re-production point. This situation points to the importance and value of visual arts teacher education in terms of its contribution to habitus in the artistic sense.

The habitus of the individual is also important to generate thoughts about the professional identity of teaching, such as the formation of artist identity. "To offer creative art activities, we undoubtedly need teachers educated in the field of visual arts with specific qualities and artistic knowledge, artistic sensitivity, artistic attitudes, and artistic skills" (Özsoy, 2007, p. 135). This need is solved by a qualified visual arts teacher education program shaped by the educational policies of our country. The lectures taken during the undergraduate program and the experiences gained with the social dynamics constitute the perception of visual arts teacher candidates regarding the teaching profession. This process creates an identity for visual arts teacher candidates against the teaching profession. While mentioning the discourses about pedagogical identities in art education, Atkinson's study (2002) emerges as a case study that benefited from Bourdieu's concepts. In this study, it is seen that Bourdieu's concepts of field, habitus, and capital are included as one of the theoretical foundations. The study was carried out through interviews with teachers to examine the field of art education and the formation of identity.

When thinking about teacher training in the field of art, we need to consider the existence of each higher education institution, in another word, each school's own habitus, which includes Arts and Crafts Education programs. In this context, we can talk about the effect of living space, school, academicians, etc. on individual habitus. This situation will theoretically enable us to evaluate different forms of practice in art, learning-teaching processes, and sources of different attitudes towards art.

Bourdieu's concepts of cultural capital and habitus help us to better understand an individual's behavior and performance (Huang, 2019, p. 49). The effect of habitus and capital on artistic thinking and tendencies will shed light on the solution and development of some problems in art education such as being an artist, being an art audience, and conveying artistic capital to students as teachers of the future. With a sociological view of artistic practices, examining the underlying factors of artistic behaviors -in the context of the art field- can allow us to discover the causes of these problems. With their research, Sankır and Sankır (2019) made the effects of families and teachers on art orientation, interest in art, and the shaping of artistic behaviors and attitudes visible in the light of Bourdieu's theory.

Candidates of visual arts teachers' art-related educational activities, cultural experiences/participation in cultural activities and having cultural products, etc. that they receive from early childhood to undergraduate education within and outside of school shape their artistic habitus. In addition to the possessed habitus, the quality of the undergraduate education and cultural experiences enrich the preferences, tendencies, and behaviors in the shape of artistic practice. The point we will pay attention to here is that the content of art education, which expands with the dynamic structure of art, can change with artistic attitudes, preferences, and behaviors with the influence of other structures and other types of capital within the field of art. The resources that support this change are organized by the social background and education of the individual. These values will manifest themselves as structures that affect artistic production and consumption in the sociological context. In general, the knowledge and skill of the individual in this sense will result in affection for the teaching profession. In summary, thinking about the artistic and educational habitus of visual arts teachers, who are a part of the continuity of cultural production and the spread of produced cultural works, will find a response as a 
determinant of artist and educator identity, and will shed light on our orientation towards more effective practices in the context of teacher education.

\section{Conclusion and Suggestions}

Our discovery of the social aspect of art is discussed in the center of art sociology. According to Erinç (2009), art sociology “. . .examines art, artist, receptive, art processes and artworks based on sociological data" (p. 9). Art sociology includes activity artistic production and institutional determinants within the scope of the topics it deals with (Wolff, 2000, p. 134). Pierre Bourdieu, who displays activity in this discipline, is one of the sociologists who think about art as well as education. Bourdieu is a sociologist who considers the formation of aesthetic ideas and values from a social perspective as a subject of study and examines the emergence of art in the focus of creation or production processes, institutions, and organizations (Zolberg, 2013, p. 16). The perspective he produced allowed us to consider the theoretical and application processes of art within the individual characteristics and social context of looking at art education.

With this study, a general framework on the basic characteristics and functioning of the artistic habitus is presented. The main reason for benefiting from Bourdieu's approach in the study is that it helps us to evaluate the function of education in artistic creation/production and consumption patterns, which are among the social institutions that are effective in the construction of artistic habitus. The development of the artistic habitus, which starts with the family and continues with the art education given in schools shaping the learning, understanding, and application processes of art, makes the family's influence and educational experiences valuable in the process.

In the studies included in this research, habitus, formation of artistic predispositions, identity building in art and education, artistic production, and consumption behavior patterns are discussed as an explanatory concept. When the studies are evaluated as a whole, it is seen that the habitus has the guiding power in artistic production and consumption. It is thought that the habitus shaped and produced by social conditions in the formation of artist identity will provide resources to individuals or artists interested in art when it is desired to examine subjects such as artistic thinking schemes, art production, determining artistic language, and artistic choices, etc. When the artistic habitus is examined on a group whose scope is drawn or determined, it can also support the reading of indicators for identity, self, motivation, and biographical research in art or art education.

The experiences we acquire consciously or not shape our intellectual structure and behaviors related to art and contribute to the formation or development of our talents and knowledge. Synthesizing this formation with the capital we have will serve to help us determine our position in the field of art. In addition to its determining feature in the field of art, the role of the habitus is important in terms of its reflections on the teaching profession and the practices in the profession. We can state that thinking about habitus in the context of art education offers a valuable theoretical perspective to produce ideas for the formation of artistic identity and educational approaches.

In this study, all rules in the "Higher Education Institutions Scientific Research and Publication Ethics Directive" were followed. None of the "Actions Against Scientific Research and Publication Ethics" in the second part of the directive have been implemented. 


\section{Türkçe Sürümü}

\section{Giriş}

Sanatsal yatkınlıklar, sanatsal deneyimlerle şekillenmektedir. İnsanın doğduğu andan itibaren sanatla ilgili tüm yaşantıları, ona sanat konusunda belirli bir algısal özellik kazandırmaktadır. Yaşantılar yoluyla kazanılan sanatsal algı sanatsal üretim, sanatsal beğeni, sanatsal tüketim gibi sanatla ilgili tutum ve davranışlara yön veren bir bilinç oluşturmaktadır. Bu bilincin oluşumunu destekleyen kaynaklar başta psikoloji olmak üzere çeşitli disiplinlere konu olabilmektedir. Bu disiplinlerden birisi de sanat sosyolojisidir. Sanat sosyolojisinde sanat beğenisi, sanatsal üretim ve tüketime yönelik çalışmalarıyla öne çıkan Pierre Bourdieu, geliştirdiği habitus kavramı ile sanatsal yatkınlıklara dair sosyolojik bir inceleme yapmamıza imkân sağlayan kuramsal bir araç sunmuştur. Habitusun, sanatsal yatkınlıkların ve estetik yargılarda farklılaşan yönelimlerin açıklanmasında yol gösterici bir kavram olarak kullanımının; sahip olunan eğitim düzeyi ve sanatsal deneyimlerle beraber sanatla kurulan ilişkilerdeki belirleyiciliğinin incelenmesinin görsel sanatlar eğitimine katkı sağlayacağı düşünülmektedir.

Bourdieu'nün habitus dışında geliştirdiği ve literatüre kazandırdığı diğer kavramlar arasında sermaye ve alan kavramlarının da yer aldığı bilinmektedir. Bu kavramlar birbirleriyle ilişkili olarak anlam kazanması sebebiyle araştırmada ele alınan önemli teorik yapıları oluşturmaktadırlar. Sermayeler (ekonomik, kültürel, sosyal ve simgesel sermaye) ve habitus tanımlama açısından farklılıklar içermektedir, fakat bu kavramlar birlikte hareket eden birbirlerini etkileyen yapıdadırlar. Alan ise bu etkileşimi kapsayan diğer önemli parçadır. Bu nedenle habitustan söz ederken alanın ve sermayelerin habitus üzerindeki etkisi düşünülerek bu kavramların birlikte ele alınması anlamlı olmaktadır.

Araştırma eğitim, sanat ve sosyoloji ilişkisine dair bir değerlendirme içermesi sebebiyle Bourdieu’nün sermaye türlerinden özellikle kültürel sermaye kavramı habitusa eşlik etmektedir. Kültürel sermaye bir bireyin sahip olduğu eğitim seviyesi anlamına gelmektedir (Danko, 2017, s. 64). Bourdieu'nün "kültürel sermaye [kavramı] kültürel bilgi, yetenek ya da eğilimlerin biçimleriyle ilgilidir” (Johnson, 1993, s. 7). Kültürel sermayeyi “...sanat bağlamında düşününce sanat eserlerinin ilgili şifrelerini çözecek ve ondan istifade edecek bilgi demek olur..." (Danko, 2017, s. 64). Kültürel sermaye, eğitim sosyolojisi ve sanat sosyolojisinde çalışma konusu olmuş bir kavramdır. Eğitim sosyolojisinde kültürel sermaye kavramı, öğrencilerin akademik başarı/okul başarısı ile ilişkisi vb. konuların incelenmesini mümkün kılarken (DiMaggio, 1982); sanat sosyolojisi kapsamında bu kavramın, aile ve eğitim yoluyla edinilen kültürel deneyimlerin, kültürel ürünlere sahip olma, eğitim düzeyi vb. durumların bireylerin sanata yönelik ilgi, tutum ve davranışlarını şekillendirmesi açısından ele alındığı görülmektedir (Bourdieu, 2015; Bourdieu \& Darbel, 2011; Sankır \& Sankır, 2019; Swartz, 2018). Bu doğrultuda aile ve okul yoluyla edinilen kültürel sermayenin, eğitsel ve sanatsal anlamda bireylerin davranışlarını yönlendirmedeki etkisi, habitus üzerine düşünürken diğer sermaye türlerine göre daha ön plana çıkmaktadır.

Aile ve okulun kültürel sermaye üzerindeki etkisi, habitusun biçimlenişiyle ve sanata yönelik verilen tepkilerde karşılık bulmaktadır. Tezcan (2016) okul sürecinin oluşturduğu habitusların bilgi, entelektüel üslup, tutum, davranış ve dil bileşimini içerdiğini ifade etmiştir. Öğretmenlerin bu süreçteki rolü göz önünde bulundurulduğunda öğretmen yetiştirme konusu ön plana çıkmaktadır. Üniversitelerin sahip olduğu okul iklimi ve müfredat/program yapısı dahilinde öğretmen yetiştirme süreci içinde gerçekleşen uygulamalar ve deneyimler, öğretmenlik meslek algısına yönelik bir kültürü meydana getirmektedir. Bu kültürün nitelikli bir öğretmen yetiştirmeye etkilerini keşfetmek adına habitusun önemli bir araç olduğu düşünülmektedir. Bu bağlamda öğretmen yetiştirme, öğretmenlik meslek sürecindeki uygulamalar ve habitus ilişkisi üzerinde düşünülmesi gereken konulardır. Çünkü eğitim yoluyla edinilen habituslar çoğalarak devam edecek ve kendisini yeniden üretecektir. Aynı zamanda eğitim, sanatsal bilincin biçimlenişinde, sanatsal beğenilerin oluşmasında ve gelişmesinde, bireylerin sanat alanındaki konumlarını belirlemede de önemli rollere sahip toplumsal kurumlardan birisi olarak ifade edilebilir. Eğitim-öğretim sürecinin sanatsal üretime ve tüketime katkılarını habitusla ilişkilendirerek keşfetmek 
DEMIR YILMAZ \& ÇAKMAKOĞLU KURU - Çukurova Üniversitesi Eğitim Fakültesi Dergisi, 50(2), 2021, 677-697

gerekmektedir. Fazlıoğlu Akın ve Ece'nin (2014) de belirttiği üzere "sanat eğitimi politikaları, bir ülkenin yaratıcı ve kültürel sermayesinin gelişmesi ve büyümesi için çok önemlidir" (s. 19). Bu sebeple, habitus kavramı ekseninde görsel sanatlar alanında öğretmen yetiştirmenin önemini anlamak; sosyolojik açıdan görsel sanatlar eğitiminin önemine dikkat çekmek gerekmektedir.

Bu araştırmanın amacı, habitus kavramı üzerine genel bir çerçeve sunmak, sanatsal habitusa dair sorgulamaların ve keşiflerin önemini gündeme getirmektir. Bu doğrultuda araştırma, habitusu görsel sanatlar eğitimi açısından ele almaktadır. Habitusu görsel sanatlar eğitimi üzerinden düşünmek, kültürel sermayenin ediniminde payı olan eğitimin -özelde ise görsel sanatlar eğitiminin- bireyin sanatsal habitusunu yapılandırıcı rolü ve sanat alanında konumlanışını yönlendiren koşullara karşı teorik bir bakış açısı geliştirmek açısından önemlidir. Bireyin sanatla ilişkisini, sanata katılımını ve pedagojik faaliyetlerini anlamak ve tanımlamak adına teori ve pratikte sanat eğitiminin rolünü, Bourdieu'nün habitus kavramına yüklediği anlam üzerinden değerlendirmenin, görsel sanatlar eğitimi adına sosyolojik bir anlatı üretmek noktasında değerli olduğu düşünülmektedir.

\section{Yöntem}

Görsel sanatlar eğitiminde habitus kavramı ile ilgili olarak genel bir değerlendirmenin yapıldığı bu araştırma derleme makalesi niteliğindedir. Araştırmada veriler literatür taraması yoluyla toplanmıştır. "Literatür taraması, araştırılan konuda diğer düşünür, araştırmacı ve uygulayıcıların ürettikleri bilgilerin bulunması, değerlendirilmesi ve sentezlenmesi ile mevcut durumun öğrenilmesi için yürütülen sistemli bir süreçtir" (Booth, Papaionnou ve Sutton'dan aktaran Karasar, 2017, s. 94). Literatür taraması ile elde edilen verilerin araştırmaya yansıtılmasında Pautasso (2013)'nun çalışmasında yer verdiği 10 temel kuraldan yararlanılmıştır. Literatür taraması yazımında önerilen temel kurallar şu şekildedir:

1. Konuyu ve hedef kitleyi belirlemek

2. Literatürü taramak ve tekrar üzerinden geçmek

3. Okurken notlar almak

4. Yazmak istenilen derlemenin türünü belirlemek

5. Derlemenin odağını dar fakat ilgi alanını geniş tutmak

6. Eleştirel ve tutarlı olmak

7. Mantıksal bir yapı oluşturmak

8. Geri bildirimlerden ders çıkarmak

9. Konu ile ilgili kişisel çalışmalarını dahil etmek fakat objektif olmak

10. Güncel olmak fakat eski çalışmaları unutmamak (Pautasso, 2013).

Yukarıda belirtilen maddeler ekseninde konu ile ilgili olarak literatürde yer alan çalışmalar araştırımış, öncü ve güncel çalışmalar incelenmiştir. Literatür ışığında habitus kavramının kuramsal temelleri açıklanmış ve özetlenmiş; habitusun temel özellikleri sanat ve görsel sanatlar eğitimi üzerinden yorumlanmıştır. Çalışmanın kuramsal yapısının sıralanması ve yapılandırılmasında iki alan uzmanından görüş alınmıştır. Görsel sanatlar eğitiminde habitus üzerine değerlendirmeyi içeren kuramsal yapı üç temel başlık altında sunulmuştur.

\section{Bulgular}

\section{Habitus Kavramı}

Habitus kavramı, Fransız Sosyolog Pierre Bourdieu'nün önemli teorik kavramlarından bir tanesidir. Habitusun çıkış noktasını ve tanımını, neye karşılık geldiğini, nelere kaynaklık ettiğini literatür taraması sonucu karşımıza çıkan bilgiler odağında ele almak gerekirse; Jourdain ve Naulin (2016) habitus kavramının, Saint Thomas d'Aquin tarafından Aristoteles'in heksis kavramının tercüme edilmesiyle ortaya çıktığını ve Bourdieu'nün kavramı yeniden yorumladığını ifade etmektedir. Bu çalışmada Bourdieu'ye göre habitus, "bireylerin sosyalleştikleri süre içinde -çocuklukta ilköğretim, yetişkinlikte ortaöğretim- az çok bilinçsiz bir şekilde içselleştirmiş ve benimsemiş olduğu idrak (dünyanın nasıl algılanacağına dair), değerlendirme (nasıl değerlendirileceğine dair) ve eylem (nasıl davranılacağına dair) şablonlarından meydana gelir" (Jourdain \& Naulin, 2016, s. 42) şeklinde tanımlanmıştır. Danko (2017) 
çalışmasında Bourdieu'nün habitus kavramını Erwin Panofsky'den aldığını ifade eder ve habitusu “içsel eğilimlerden oluşan; sosyalleşme sayesinde kazanılan düşünce, algı ve eylem şemalarından oluşan bir sistem" (s. 59) olarak tanımlar. Swartz'da (2018) çalışmasında Erwin Panofsky'nin fikirlerinin Bourdieu'nün habitus kavramını oluşturmasında yardımcı olduğunu belirtmiştir. Bourdieu'nün çalışmaları ve fikirleri üzerine düşünen bu kaynaklara temel oluşturacak görüşlerine Bourdieu Sanatın Kuralları adlı çalışmasında yer vermektedir. Habitus kavramının temelleri üzerine Bourdieu, Panofsky'nin iki makalesinin Fransızca yayımlanmasıyla yararlandığını, Aristocu heksis kavramının habitusa dönüşümü ile habitus kavramının kullanımını yeniden yorumladığını belirtmiştir (Bourdieu, 2020, s. 313-314).

Yine bir diğer kaynakta habitus, “...bedensel tavır, konuşma şekilleri ya da düşünme ve hareket etme biçimleri gibi insanların içinde bulundukları toplumsal koşullarla ilişkileri bakımından benimsedikleri öğrenilmiş yetenekler olarak açıklanabilmektedir" (Giddens \& Sutton, 2016, s. 901). Bourdieu'nün çalışmaları üzerine düşünen Swartz'da (2018) habitusu şu şekilde ifade etmiştir:

Bourdieu, bu kilit kavrama işaret etmek üzere "kültürel bilinçdışı", "alışkanlık oluşturan güç", "temel, derinlemesine içselleştirilmiş büyük örüntüler", "zihinsel alışkanlıklar", zihinsel ve bedensel algı, beğeni ve eylem şemaları", "düzenli doğaçlamaların üretici ilkesi” gibi ifadeleri kullanır. Kavramın kapsamı, zamanla, eylemin hem bilişsel hem de bedensel temelini vurgulayacak ve alışkanlık haline gelmiş eylemlerin yanı sıra yaratıcı eylemleri de içine alacak şekilde genişler (s. 144-145).

Bourdieu'nün habitus üzerine düşüncelerinin temelinde Aristoteles, Saint Thomas d'Aquin, Emile Durkheim, Norbert Elias, Marcel Mauss, Max Weber gibi pek çok kişinin etkisinden söz edilmektedir (Jourdain \& Naulin, 2016, s. 42). Araştırma kapsamında yer verilen Bourdieu üzerine yapılmış çalışmalarda habitusa yüklenen anlamlar benzer özellikte karşımıza çıkmaktadır. Kavram genel olarak, düşüncelerimize, davranışlarımıza, eğilimlerimize ve yatkınlıklarımıza işaret etmektedir. Sosyolojik konular içerisinde yer alan habitusun, temellerinde psikolojiden beslendiği görülmektedir. Bilişsel yapı ekseninde, sosyal koşullar etkisinde varlık göstermektedir şeklinde ifade edilebilir.

Habitusla ilgili değinilen önemli bir nokta hem yapılanmış hem de yapılandırıcı yapıda olmasıdır (Swartz, 2018, s. 148). Habitus hem bireyler tarafından üretilir hem de bireyleri etkiler özelliktedir. Hardy'nin (2009) çalışmasında değindiği habitusun doğrudan ölçülmediği, bireysel ve kolektif olarak üretildiği, belirli bir coğrafi ve zamansal bağlam içinde çözümlemenin değerli olduğu, farklı sermaye türlerinin birleşiminden doğduğu, alan ile etkileşimli işlediği, bazı değişkenler (yaş, sosyal statü, aile kökeni vb.) açısından değişiklikler gösterebileceği, zaman içinde dönüşebilir, değişebilir ve gelişebilir olduğu gibi bazı özellikler dikkat çekicidir. Buradan hareketle habitusu keşfetmeye dair bir inceleme yapılmak isteniliyorsa bu özelliklerin göz önünde bulundurulması gerekmektedir.

Habitus, içerdiği anlam bakımından bireye dair birtakım verileri açıklayıcı kılmaktadır. Habitusun sahip olduğu anlamı sanatsal bağlamda düşünmenin, sanat ve sanat eğitimi üzerine yapılacak değerlendirmeler için önemli olduğu düşünülmektedir.

\section{Habitus ve Sanat: Sanatsal Habitus}

Sanatın tek bir tanımından söz etmek ve sanat tanımını sınırlandırmak özellikle günümüzde pek anlamlı olmayacaktır. Sanatı izleyen ve üreten açısından sanata yüklenen anlamlar genişlemektedir. İnsanlık var olduğundan ve sanatın sanat olarak nitelendirilmesinden bu yana sanatı üretmenin, sanata katılmanın ve sanatı anlamlandırmanın yöntemleri çoğalmıştır. Farklı tarihsel dönemlerde farklı kültürlerin sanatsal üretimlerinin genişliği birtakım değerlendirmeleri de çoğaltmıştır. Sanat üzerine konuşmanın, sanatı anlamanın ya da sanatı üretmenin doğası sanatsal eğilimlerin/tercihlerin farklılaşması gibi bir durumla karşılaşılmasına neden olmaktadır. Ortak bir noktada buluşma sorunsalı estetik beğeni, estetik haz, estetik tercih gibi kavramlar ile açıklanmaya çalışılmaktadır. Farklı disiplinlerin içerdiği kavramlar, bu açıklamalara yardımcı, sanatın kendi içindeki terminolojisine destek olacak bir bakış açısı sunabilmektedir. Bu noktada habitus kavramını sanat üzerinden düşünmenin, sanatın sosyolojik anlamda bir analizini yapmada, sanatsal yaklaşımların ya da eğilimlerin nedenleri ile ilgili 
fikirler oluşturulması ve sanatsal davranışların anlamlandırılması açısından yol gösterici olacağı düşünülmektedir.

Illk olarak, sanatçı kimliğin çözümlenmesinde önemli kuramsal dayanaklardan birisi olarak habitus üzerine düşünmek gerekmektedir. Habitus, sanaţ̧ı kimliğin oluşumu ve devamlılığını etkileyen bir özellik göstermektedir. Bireysel özellikler ve sosyal koşullar etkisinde sanatçı kimliğin oluşumunda habitus etkin bir rol oynamaktadır. Bireyin yaşamında aile ve eğitimi yoluyla örtük ya da doğrudan deneyimlediği, farkında olarak ya da farkında olmadan sanatla kurduğu ilişkiler sanatsal kimliğin oluşumunun bir parçası olarak değerlendirilmelidir. Yaşam alanında şekillenen habitus, sanatsal düşünme şemaları, sanatı üretme yolları, sanatsal dili belirleme, sanatsal seçimler, sanatsal faaliyetlere katılım vb. konularda etkili olabilecek bir bilgiye ve kültüre sahip olma durumunu ortaya çıkarmaktadır. Bireyin sanata dair içselleştirdiği kalıplar, sanatsal kimliğini oluşturacak, sanat üretim ve tüketim biçimlerinde kendini gösterecektir. Bu sebeple sanatçı kimliğin oluşumu ve tanımında habitus önemli bir işleve sahiptir.

Habitusla ilgili olarak bir diğer üzerinde durulması gereken konu zaman içinde değişip, dönüşebilir özelliğe sahip olmasıdır. Bireyin sanat bilgisi yani bir anlamda kültürel sermayesi diğer sermaye türleri ile desteklendiğinde habitusunda gelişim ve değişimler söz konusu olabilmektedir. Jourdain ve Naulin'nin (2016) "habituslar, herkesin yaşam koşullarına ve izlediği toplumsal yola göre değişiklik gösterir" (s. 43) şeklinde belirttikleri bu durumu sanat bağlamında düşünmemiz gerekirse, sanatın dinamik ve sürekli genişleyen yapısıyla birlikte, habitus ve sermayelerin de kişiden kişiye değişiklik göstermesi, sanatsal habitusun değişebileceği anlamına gelmektedir. Kişinin sermayelerinden birinin bile yükselmesinin habitusunun değişmesi anlamına gelebileceğidir (Biçer Olgun, 2019, s. 54).

Sanat ürünlerinin, sanat yapıtlarının ya da eserlerinin ortaya çıkışını ve alımlanmasını da habitus kavramı üzerinden düşünmek gerekmektedir. İnsanın sanatsal deneyimleri ve estetik beğenisinin, üretim sürecine yansımaları olduğu ve somut bir şekilde sanat ürünlerine dönüştüğü bilinmektedir. Bu noktada sanat ürünleri, yapıtları ya da eserleri kısaca sanat nesnesi üreten bireyin sahip olduğu habitusun, sanat nesnesinin yapısal ya da düşünsel özellikleri üzerinde şekillendirici rol ve etkilere sahip olduğu ifade edilebilir. Bu bağlamda sanat nesnesini, habitusun önemli bir parçası olarak değerlendirmek mümkündür. Bourdieu, sanat nesnelerinin ortaya çıkışına dair sanatsal üretim alanının etkisine yönelik düşünceleri ile karşımıza çıkmaktadır.

Öyleyse yapıt'ın konusu, diye özetler Bourdieu, bir habitus'la bu habitusun konumlandığı yerdir, öbür deyişle bir alan [...]. Sanat yapıtının izlerini taşıdığı sosyal determinizmler üretenin sahip olduğu habitus'un içinden geçerek etkide bulunurlar, ve üretimindeki sosyal koşullara gönderirler: sosyal özne olarak (aile, vb.), üreten olarak (ekolü, meslek temasları, vb.) içinden geçtiği koşullara gönderirler. Sosyal determinizmler ayrıca sanat üretenin belirli bir üretim alanında (belli ölçüde otonom bir alanda) tuttuğu pozisyonda şekillenmiş olan talepler ve sosyal baskılar aracığılla etkide bulunurlar. "Eser yaratma" dediğimiz olgu sosyal olarak kurulmuş bir habitus'la bir kültürel üretim çalışmasının sosyal işbölümünde edinmiş olduğu ya da olası bir pozisyonun bir araya gelmesidir [...].

Böylece, sanat yapıtının öznesi ne özgün bir sanatçıdır (sanatçı görünür neden'dir), ne de bir sosyal grup [...]. Özne bir bütün olarak sanatsal üretim alanı'dır [...] (Bourdieu'den aktaran Heinich, 2013, s. 102).

Burada yer verdiği ifadeler ile Heinich (2013), sanatsal üretimin kaynağının bir bütün olarak değerlendirilmesine dikkat çekmiştir. Bir diğer kaynakta sanat üretiminde sanat alanı ve habitusun ilişkisinin derecesi şu şekilde belirtilmiştir:

Kültürel eserlerin sosyolojisinin nesnesi, sanatçı ve sanatçılar arasındaki ilişkilerin (nesnel olanlar ile etkileşim biçiminde gerçekleşenlerin) bütünü ve bunların ötesinde eserin ya da en azından eserin toplumsal değerinin üretimine müdahil olmuş aktörlerin bütünü (eleştirmenler, galeri yöneticileri, hamiler vb.) olmalıdır... Insanların "yaratım" dediği şey, kültürel üretim iş bölümünde (ve dahası ikinci bir düzeyde) tahakküm iş bölümünde olası ya da oluşmuş bulunan habitusun birleşmesidir (Bourdieu'den aktaran Zolberg, 2013, s. 130). 
Bu durum, sanatçının ve sanat eserinin ortaya çıkışında habitusun işleyişini göstermektedir. Sanat sosyolojisi üzerine çalışmalarıyla bilinen Heinich (2013), habitus kavramı ile ilgili olarak “...bir fotoğrafın kalitesini yargılama, ya da bir müzede yol bulmaya olanak veren şey, aktörlerde içselleşmiş olan bu "yetiler düzeni", "habitus"dur" (s. 65) şeklinde belirtmiştir. Heinich'in (2013) ifadelerinden de anlaşılabileceği gibi, sanat bağlamında habitus, bir sanat üreticisi, izleyicisi, alımlayıcısı olarak davranışlarımıza yön veren içsel bir düzene karşılık gelmektedir. Bu düzeni açığa çıkarmak için bir mekân gerekmektedir. Bourdieu'nün 'alan' olarak ifade ettiği kavramda bu mekâna karşılık gelmektedir. Giddens ve Sutton (2016) Bourdieu'nün alan kavramını, “...rekabetçi mücadelelerin gerçekleştiği çeşitli toplumsal mekanlar ya da arenalardır" (s. 901) şeklinde tanımlamaktadır. Alanla etkileşim içinde olması, habitusu keşfetmek adına önemli bir özelliktir. Alan konusunu, sanat alanı bağlamında düşünmek gerekmektedir. Sanat alanı üzerine Bourdieu (2020) şunları ifade etmiştir:

...sanatsal, büyük ya da küçük, ünlü, bir başka deyişle yüceltilmiş veya tanınmayan olarak sınıflandırılan tüm yapıt üreticilerini, kendileri de bir alan oluşturan eleştirmenleri, koleksiyoncuları, aracıları, müze müdürlerini kısacası sanatla bağlantısı olup sanat için yaşayan ve ekmeğini sanattan kazanıp sanat yapıtının anlam ve değerinin tanımlanması, dolayısıyla sanat ve (gerçek) sanatçı dünyasının sınırlarının belirlenmesi adına sürdürülen rekabet sürtüşmeleri içinde birbirleriyle karşıtlaşan ve bu çatışmalar aracılığıyla sanat ve sanatçının değerinin üretimine katkıda bulunan herkesi işin içine katar (s. 501).

Bourdieu'nün Kültürel Üretim Alanı (The Field of Cultural Production: Essays on Art and Literature) isimli çalışmasında bir eserin doğrudan üreticisine ilave olarak eserin anlam ve değerine katkıda bulunan, sanat eserini bilme ve tanıma yeteneğine sahip tüketiciler üreten öğretmenler ve ailelerin de alanın içine dahil olduğu görülmektedir (Bourdieu, 1993, s. 37). Bu doğrultuda, yaratıcı sürecin nasıl şekillendiğine bir kaynak olarak Bourdieu'nün alan kavramı, sermayeler ve habitus kavramlarının tamamlayıcısı olarak bir özellik göstermektedir.

Örneğin sanat ve estetik alanında kültürel sermaye en çok değer verilen sermaye biçimidir ve sanat tarihi ya da müzik konusunda en bilgili konuşabilen kişiler, alan içinde güçlü hale gelir; bu nedenle edebiyat ya da sinemada, eleştirmenlerin bir kitabın ya da filmin başarısı ya da başarııızlığı üzerinde büyük bir etkisi olabilmektedir (Giddens \& Sutton, 2016, s. 901).

Yine bir sanat eserini okuma ve anlamlandırma üzerine düşündüğümüzde ya da görsel kültür bağlamında genel anlamda görsel olanı okumak için Schirato ve Webb'in (2004) "okumanın hem aktif hem de yaratıcı bir süreç olduğunu savunuyoruz; ve görseli okurken, gördüklerimizi anlamlandırmak için genel ve özel bilgilerimizden, zevklerimizden, alışkanlıklarımızdan ve kişisel bağlamlarımızdan (Pierre Bourdieu'nun Habitus dediği şey) yararlanıyoruz" (s. 6-7) şeklindeki ifadeleri habitusun sanat ile bağlarıı düşünmemize imkan vermektedir. Bir eser analizi yaparken ya da görsel kültüre dair imajları sorgularken bilgimiz ve deneyimlerimizin yönelişi habitusumuz dahilinde tepkiler vermemizle sonuçlanmaktadır. Webb, Schirato ve Danaher (2002) habitusu şu şekilde tanımlar:

Bir yandan, bireylerin kendileri haline gelme biçimini -tutum ve eğilimleri geliştirmeyi- ve diğer yandan bu bireylerin uygulamalara katılma yollarını ifade eden bir kavram. Örneğin bir sanatsal habitus, bireysel sanatçıyı, sanatsal alanın kültürel ve tarihsel olarak oluşturulmuş değerlerini ifade eden belirli etkinliklere ve bakış açılarına sevk eder (s. xii-xiii).

Habitusun davranışlarımızı etkileyen yapısı üzerine Danko'da (2017) “...insanın neyi nasıl icra edeceği ve ondan nasıl istifade edeceğinde sosyal konum ve habitus mühim bir rol oynamaktadır" (s. 59) ifadelerinde bulunmuştur. Bu görüşler ile birlikte sanatsal üretim/yaratıma ve alımlamaya etki eden, içsel ve dışsal anlamda bireyi harekete geçiren güç habitus bağlamında değerlendirilebilir. Habitus bu anlamda bireyin sanatla ilgili davranışlarını yönlendirme ve açıklamada etkili bir rol oynamaktadır.

Habitus üzerine düşünürken göz önünde bulundurulması gereken önemli bir noktada zaman ve bağlamdır. Belirli bir dönemde belirli bir gruba dair estetik tercihlerin kendi zamanı içinde değerlendirilmesi sanatın üretim ve alımlama/tüketim biçimleri açısından sosyolojik analizini anlamlı hale getirecektir. Bu durum bizleri, habitusun zaman ve mekân bağlamında değerlendirilmesine 
yönlendirmektedir. Habitusun zaman ve mekân bağlamında kapsamı çizilmiş bir örneklem üzerinde değerlendirilmesi örneği Hardy ve Grenfell (2006) çalışmalarında ele alınmıştır. Çalışma Bourdieu'nün teorik perspektifinden yola çıkarak sanatsal biyografik bir inceleme özelliği göstermekle beraber sanatçıların sosyal, ekonomik, kültürel sermayeleri ve sanat alanı ekseninde avangart sanatçının oluşumunu keşfedici analizler sunmaktadır. Burada sanatçı hakkında veriler elde etmek için sanatçının habitusunun keşfinde biyografik yaklaşım kullanılmıştır. Biyografik araştırmalar öznelerin deneyimlerine odaklanarak, sosyal yapı ile ilişkilerini açıklamak için kullanılmaktadır (Güvercin, 2017). Sanatsal biyografik analizle alandaki sanatçıların konumlarını nasıl elde ettikleri hakkında fikir edinme, kültürel üretim alanına dair göstergeler içermesi sebebiyle dikkat çekici bir çalışmadır.

Sanatla ilgili önemli konulardan biri de yetenektir. Uygun koşulların etkisinde sanatsal yeteneğin keşfi gerçekleşir. Keşfedilen sanatsal yeteneğin gelişimi desteklenirse bireyin yaşamı sanatla bütünleşebilir. Aile, sanatsal anlamda bir yeteneğe yönelik keşfin ortaya çıkarıldığı ilk ortamdır. Yeteneğin keşfinde önemli bir yere sahip olan aile, aynı zamanda sanata ilginin, sanatsal beğeninin, sanata yönelmenin ortamını da oluşturmaktadır. Erinç (2009) yeteneğin genetik özelliğinin yanı sıra önemli bir diğer faktöründe ailenin tutum ve davranışları olduğunu ifade etmiştir. Sanatsal faaliyetleri destekleyen ailelerin daha çok sanatla ilgilenen, sanat bilgisine sahip olan aileler oldukları ifade edilmektedir (Ulusoy, 2005 , s. 143). Sanatla ilgili bir mesleğe yönelimde ailenin rolü ile bu durum daha anlamlı hale gelmektedir. Çünkü ailenin sanata ilgisi ve sanata verdiği değer çocuğa aktarılacaktır (Tezcan, 2011, s. 81). Burada geçen ifadeler doğrultusunda habitusun aktarılabilir olma durumu, sanatsal açıdan habitusun oluşumunda ailenin rolünü değerli hale getirmektedir. Yeteneğin ortaya çıkışı ve sanatçı olana kadar geçen süreçte, kişinin sermayelerinin ve habitusunun etkisine dikkat çekmek gerekmektedir. Bireyin, toplumsal dinamikler içindeki gelişimi, yani habitusu, sanatçı kimliğini oluşturmasında ne gibi bağlantılarla, imkanlarla ve birikimlerle, sanata karşı nasıl bir yaklaşım geliştirdiğine; sanat alanındaki tanınırlığını nasıl elde ettiğine dair bir çözümlemeyi olanaklı kıldığı için, sanatçı kişi üzerine yapılacak bir inceleme, sanatçı olmak isteyen bireylere örnek teşkil edecek ve yol gösterici olacaktır. Konu ile ilgili olarak kapsamlı bir bakış açısı Grenfell ve Hardy'nin (2003) çalışmasında yer almaktadır. Çalışmada çağdaş İngiliz sanatçılar örnekleminde sanat alanı ve habitus ilişkisi incelenmiştir. Avangart sanatın süreçleri ve işleyişi Bourdieu'nün teorisi bağlamında ele alınmıştır. Türkiye bağlamında bir inceleme Biçer Olgun (2019)'un çalışması ile karşımıza çıkmaktadır. Biçer Olgun (2019) görsel sanatlar alanında 9'u küratör, 16'sı sanatçı olmak üzere 25 katılımcıyla gerçekleştirdiği çalışmasında sanatçı kimliğinin nasıl inşa edildiğini, sanat eserinin ne olduğunu, nasıl değer kazandığını ve toplumsal olarak hangi toplumsal aktörler aracılığıyla üretildiğini, sanat eserinin değerinin toplumsal açıdan nasıl inşa edildiğini sosyolojik açıdan incelemiştir. Bu çalışmanın kuramsal dayanakları arasında Bourdieu'nün sermayeler, habitus ve alan kavramları da yer almaktadır. Yine bu çalışmada da sanat alanında habitus ve sermayelerin gücüne dikkat çekilmiştir. Bu yolda ilerlemek isteyen bireylere yardımcı olacak bir yol haritası sunacak olması sebebiyle, sanat alanı ve sanatçı habitusu üzerine yapılacak çalışmaların önemli olduğu düşünülmektedir.

Sanatsal beğeni ve tercihlerimiz üzerinde de habitusun rolünden söz etmek gerekmektedir. Sanatta yaşanan değişim ve dönüşümlerle birlikte, sanatsal değer yargılarının oluşumu ve gelişimi hakkındaki yönelimlerde çeşitlenmektedir. Sanat yapıtlarını değerlendirme ve sanatsal beğenide farklılaşmalara neden olabilmektedir. Pek çok unsur bu konuya zemin hazırlayabilmektedir. Bireyin yaşam alanı özellikleri, kültürel yaşamı, aile yapısı, cinsiyeti, eğitimi, yaşı vb. unsurlar beğeni üzerinde etkili olabilmektedir. Sanat beğenisi ve habitus ilişkisi noktasında Bourdieu'nün Ayrım isimli çalışması önemli bir yere sahiptir. Bourdieu çalışmasında konu üzerine sınıfsal açıdan bir yaklaşım sergilemiş; sanat ve beğeniye dair sorgulamalarını bu bağlamda ele almıştır (Bourdieu, 2015). Zaman içinde sanatsal tercihler veya beğeniler üzerinde farklı bakış açıları gündeme gelmiştir. Yakın tarihli bir sergi olan Pera Müzesi'nde gerçekleşen, Zevk Meselesi isimli sergi konu ile ilgili dikkat çekici bir örnek olarak karşımıza çıkmaktadır (bkz. Pera Müzesi, t.y.). Türkiye'de gerçekleşen sergi beğeninin sınıfsal olduğu yaklaşımına ilave olarak beğeniyi besleyen kaynakları görsel kültür, kiç, dijital kültür bağlamında sorgulamaktadır. Sanatsal beğeni konusunda değinilmesi gereken önemli bir noktada kültürel hepçilleşme, kültürel açılım ve erime senaryosu kavramlarıdır (Karademir Hazır \& Purhonen, 2017). Bu kavramlar sanat tanımının, sanata katılımın ve beğenilerin genişlemesine, kültürel ögeler veya türler arasındaki hiyerarşik düzenin ve 
sınıflandırmaların esnekleşmesine işaret etmektedir (Karademir Hazır \& Purhonen, 2017; Karademir Hazır \& Warde, 2016). Aynı zamanda sanata erişebilirlik/ulaşılabilirlikte kitle iletişim araçlarının etkisi, görsel kültürün hakimiyeti, kitle kültürü ve küreselleşme kaynaklı durumlar sanatsal deneyimin yollarını genişletmiştir. Sanatsal yaratımın ve deneyimin bu özelliği sanatsal beğeniyi de etkileyen bir durum olarak karşımıza çıkmaktadır.

Habitusu etkileyen ve şekillendiren toplumsal yapının öğelerinden birisi de eğitimdir. Genel eğitim sistemi içerisinde sanat eğitimi ise sanatsal habitusun beslenmesi ve sanat alanı içindeki hareketlerimizi yönlendirme konusunda belirleyici bir uzmanlık olarak karşımıza çıkmaktadır. Bu başlık altında sanatçı kimliği ve sanat alanında konumlanışı yönlendiren etmenlere karşı teorik bir bakış açısı geliştirmek açısından sanatsal habitus konusu üzerinde durulurken bir sonraki başlık içerisinde sanat eğitiminde habitusu düşünmek, eğitimin -özelde görsel sanatlar eğitiminin- sanatsal habitusu yapılandırıcı rolü, sanat eğitiminde pedagojik faaliyetler, teori ve pratikte sanat eğitiminin/eğitimcisinin işlevini değerlendirmek anlamlı olacaktır.

\section{Görsel Sanatlar Eğitimi ve Habitus}

Sanatçılar, sanat eleştirmenleri, küratörler, galeri sahipleri, sanat malzemeleri üretenler ve pazarlayanlar vb. gibi sanat alanını oluşturan yapılardan bir tanesi de eğitim kurumlarıdır. Bu anlamda görsel sanatlar eğitimi, sanat alanın dinamiklerinden biri olarak karşımıza çıkmaktadır. Bu sebeple, habitus kavramının değerlendirilmesinde eğitimin rolü ele alınacak önemli noktalardan birisidir. Sanat alanı bağlamında sanat eğitimin derecesi ve niteliği, alanın dinamiklerini etkileyecek özelliktedir. Sanat alanına katılma ve alandaki mücadelesinde bireyin eğitiminin rolü üzerine düşünmek gerekmektedir. Eğitim sürecinin habitusu etkileyen bir süreç olması, sanatla ilgili eğitimin sanatsal habitusu şekillendirmesi, sanat alanı içindeki hareketlerimizi yönlendirecek boyutlardan biri olarak karşımıza çıkması, sanat alanı içinde öğretmenlerin rolünü değerli hale getirmektedir. Sanat eğitimi içinde görev ve sorumlulukları ile öğretmenlerin (sanat eğitimcilerinin) sanatsal habitusları şekillendirici işlevine dikkat çekmek gerekmektedir.

Illk öğrenme deneyimlerini aile ile gerçekleştiren bireyin, okul sürecine dahil olduktan sonra kültürel sermaye birikimi ve dolayısıyla habitusunun şekillenişi devam eder. Bu durum, belirli bir alan odağında düşünüldüğünde -ki biz sanat alanı odağında düşünüyoruz- bireyin tutumları ve eğilimlerine yön verecektir. Sanat alanındaki ilerleyişte ve mücadelede bireyin sahip olduğu sermayelerin ve habitusun etkisi bir bütün olarak hareket etmektedir. Eğitim, bu harekete kaynaklık eden toplumsal kurumlardan bir tanesidir. Eğitimin okul yoluyla oluşturduğu habitusu sanat açısından görsel sanatlar eğitimi bağlamında değerlendirmek gerekmektedir.

Sanat eğitimi almış bireylerin sanatsal ve estetik olana yönelik tutumları ve tercihleri üzerine düşünmek, bu tutumlar ve tercihlerin pedagojik olarak ortaya çıkaracağı doğurgular bağlamında önemli görülmektedir. Görsel sanatlar öğretmeni olarak görevini yapmakta olan bir bireyin estetik tercihleri, pedagojik içeriğin seçiminde açığa çıkacaktır. Sanat bilgisi (Sanat Tarihi, Sanat Felsefesi, Sanat Eleştirisi ve diğer sanat bilimleri) entelektüel bilincin inşasında önemli bir yere sahiptir. "... bir sanat eserini kendi yoğunluğuyla, tarzıyla, dahası varoluşuyla anlamak, bakan kişinin, eserin türüne ve esere özgü koda ne kadar hâkim olduğuna (diğer bir deyişle sanatsal yetkinliğine) bağııdır ve bu hakimiyet de kısmen okulda gördüğü öğrenimden kaynaklanır..." (Bourdieu \& Darbel, 2011, s. 92). Örneğin, Sanat Tarihi derslerinde yer verilen görsellerin seçimi, sunumu ve aktarımı sanatı düşünme, anlama ve değerlendirme şemalarımızı şekillendiren pedagojik yaklaşımı içermektedir. Bu yaklaşımın kültürel sermayelere etkisi ve dolayısıyla habituslar üzerindeki etkisi sanata karşı verilen tepkilerde, dirençlerde, tutumlarda kendisini gösterecektir. Sanat Tarihi içinde yer alan akımlar ya da hareketler ile birlikte sanat eserleri hakkında bir bilgi sunulmaktadır. Sunulan bilgi, eğitim yoluyla edinilen kültürel sermayeye katkı sağlamaktadır. Bu katkı bireyin habitusunu dolayısıyla etkilemektedir. Hem sanat üretimi açısından sanatsal uygulamalara hem de pedagojik faaliyetlere yansımaları söz konusu olacaktır. Habitus, öğrenme-öğretme sürecinde yer alacak sanatsal görsellerin ve etkinliklerin belirleyicisi olarak işlev görecektir. 
DEMIR YILMAZ \& ÇAKMAKOĞLU KURU - Çukurova Üniversitesi Eğitim Fakültesi Dergisi, 50(2), 2021, 677-697

Sanatsal bilgi her öğretmen adayı ile öğretmenlik mesleği sürecinde öğrencilere aktarılarak sanatsal tutumlar ve tercihlerin inşasına katkı sağlanmaktadır. Bu okul ortamında eğitim yoluyla oluşan habitustur. Bu durum başka bireylerin habituslarını etkileyecek güçte rol oynayacaktır. Eğitim yoluyla gerçekleşecek aktarımlar ve deneyimler yeniden üretim noktasında bir işlev görecektir. Bu durum, sanatsal anlamda habituslara katkıları bakımından görsel sanatlar öğretmen eğitiminin önemine ve değerine işaret etmektedir.

Bireyin habitusu, sanatçı kimliğinin oluşması gibi öğretmenlik meslek kimliğine dair düşünceler üretmek adına da önemlidir. "Belirli niteliği olan ve yaratıcı sanat etkinlikleri sunmak için sanat bilgisine, sanatsal duyarlılığa, sanatsal tutumlara ve sanatsal becerilere sahip görsel sanatlar alanında yetiştirilmiş öğretmenlere kuşkusuz ihtiyacımız vardır" (Özsoy, 2007, s. 135). Bu ihtiyacın giderilmesi, ülkemizin eğitim politikaları ile şekillenen nitelikli bir görsel sanatlar öğretmeni yetiştirme programı ile çözümlenmektedir. Lisans döneminde alınan dersler ve toplum dinamikleri ile edinilen yaşantılar, görsel sanatlar öğretmen adaylarının öğretmenlik mesleğine ilişkin algısını oluşturmaktadır. Bu süreç, görsel sanatlar öğretmen adaylarının, öğretmenlik mesleğine karşı bir kimlik oluşumunu meydana getirmektedir. Sanat eğitiminde pedagojik kimliklere dair söylemleri üretirken Bourdieu'nün kavramlarından yararlanmış bir örnek çalışma olarak Atkinson'ın (2002) çalışması karşımız çıkmaktadır. Bu çalışmada kuramsal dayanaklardan biri olarak Bourdieu'nün alan, habitus ve sermaye kavramlarına yer verildiği görülmektedir. Çalışma, sanat eğitimi alanı ve kimlik oluşumunu incelemek amaçlı öğretmenlerle gerçekleştirilen görüşmeler üzerinden gerçekleştirilmiştir.

Sanat alanında öğretmen yetiştirme üzerine düşünürken Resim-İ̧ Öğretmenliği programları içeren her yükseköğretim kurumunun yani her okulun kendi habitusunun varlığını da göz önünde bulundurmamız gerekmektedir. Bu bağlamda bireysel habituslar üzerinde yaşam alanının, okulun, akademisyenlerin vb. unsurların etkisinden söz edebiliriz. Bu durum sanatta farklı uygulama biçimleri, öğrenme-öğretme süreçleri, sanata karşı farklı tutumların kaynaklarını değerlendirmemize kuramsal açıdan olanak sunacaktır.

Bir bireyin davranışını ve performansını daha iyi anlamamıza Bourdieu'nün kültürel sermaye ve habitus kavramları yardımcı olmaktadır (Huang, 2019, s. 49). Habitusun ve sermayelerin sanatsal düşünme ve eğilimler üzerindeki etkisi, sanatçı olmak, sanat izleyicisi olmak ve geleceğin öğretmenleri olarak öğrencilerine sanatsal sermaye kazandırmak gibi sanat eğitimindeki birtakım problemlerin çözümlenmesine ve geliştirilmesine ışık tutacaktır. Sanatsal uygulamalara sosyolojik anlamda bir bakışla, sanatsal davranışların altında yatan faktörleri -sanat alanı bağlamında- irdelemek bu problemlerin nedenlerini keşfetmemize olanak sunabilir. Sankır ve Sankır (2019) yaptıkları araştırma ile sanata yönelim, sanata ilgi, sanatsal davranış ve tutumların şekillenişi üzerine aile ve öğretmenlerin etkilerini Bourdieu'nün teorisi ışığında görünür kılmışlardır.

Görsel sanatlar öğretmen adaylarının erken çocukluk döneminden lisans eğitimi dönemine okul içi ve okul dışında aldıkları sanatla ilgili eğitim-öğretim faaliyetleri, kültürel deneyimleri/kültürel faaliyetlere katılımları ve kültürel ürünlere sahip olma vb. durumları sanatsal habituslarını biçimlendirmektedir. Sahip olunan habitusa ek olarak lisans dönemindeki eğitimin niteliği ve kültürel deneyimleri, sanatsal uygulama şekillerindeki tercihleri, eğilimleri, davranışları zenginleştirmektedir. Burada dikkat edeceğimiz nokta, sanatın dinamik yapısı ile genişleyen sanat eğitimi içeriği, sanat alanı içinde yer alan diğer yapıların ve diğer sermaye türlerinin etkisiyle sanatsal tutumların, tercihlerin ve davranışların değişebilmesi durumudur. Bu değişimi besleyen kaynaklar bireyin sosyal arka planı ve eğitimi tarafından organize edilmektedir. Bu değerler sosyolojik bağlamda sanatsal üretime ve tüketime etki eden yapılar olarak karşımıza çıkacaktır. Genel olarak, bireyin bu anlamdaki bilgi ve becerisi öğretmenlik mesleğine yansıması ile sonuçlanacaktır. Özetle, kültürel üretimin devamlılı̆̆ı ve üretilmiş kültürel eserlerin yayılımının bir parçası konumundaki görsel sanatlar öğretmenlerinin sanatsal ve eğitsel habitusları üzerine düşünmek, sanatçı ve eğitimci kimliğinin bir belirleyicisi olarak karşılık bulacak ve öğretmen eğitimi bağlamında daha etkili uygulamalara yönelmemize ışık tutacaktır. 


\section{Sonuç ve Öneriler}

Sanatın toplumsal yönünü keşfetmemiz, sanat sosyolojisi kaynaklığında ele alınmaktadır. Erinç'e (2009) göre sanat sosyolojisi “...sosyolojik verilerden hareketle sanatı, sanatçıyı, alıcıyı, sanat süreçlerini ve sanat eserlerini irdeler" (s. 9). Sanat sosyolojisi ele aldığı konular kapsamına sanatsal üretim etkinliğini ve kurumsal belirleyenlerini dahil etmektedir (Wolff, 2000, s. 134). Bu disiplin içinde etkinlik gösteren Pierre Bourdieu eğitimin yanı sıra sanat üzerine düşünen sosyologlardan biri olarak karşımıza çıkmaktadır. Bourdieu toplumsal açıdan estetik fikir ve değerlerin nasıl oluştuğunu çalışma konusu edinen, sanatın meydana gelişini yaratım veya üretim süreçleri, kurumlar ve örgütler odağında inceleyen bir sosyologtur (Zolberg, 2013, s. 16). Onun üretmiş olduğu bakış açısıyla sanat eğitimine bakmanın sanatın teorik ve uygulama süreçlerini, bireysel özellikler ve sosyal bağlam içinde ele almamıza olanak sunmuştur.

Bu çalışma ile sanatsal habitusun temel özelliklerine ve işleyişine dair genel bir çerçeve sunulmuştur. Çalışmada Bourdieu'nün yaklaşımından faydalanılmasının temel nedeni, sanatsal habitusun inşasında etkili olan toplumsal kurumlardan eğitimin sanatsal yaratım/üretim ve tüketim kalıplarındaki işlevini değerlendirmemize yardımcı olmasıdır. Aile ile başlayan ve okullarda verilen sanat eğitiminin sanatı öğrenme, anlama ve uygulama süreçlerini şekillendirmesiyle devam eden sanatsal habitusun gelişimi, süreçte ailenin etkisini ve eğitim deneyimlerini değerli hale getirmektedir.

$\mathrm{Bu}$ araştırmada yer alan çalışmalarda habitus sanatsal yatkınlıkların oluşumu, sanatta ve eğitimde kimlik inşası, sanatsal üretim ve tüketimdeki davranış kalıplarını açıklayıcı bir kavram olarak konu edinilmiştir. Çalışmalar bütünüyle değerlendirildiğinde sanatsal üretim ve tüketimde habitusun yönlendirici gücü bulunduğu görülmüştür. Sanatçı kimliğinin oluşmasında toplumsal koşullar ile şekillenen ve üretilen habitusların, sanatsal düşünme şemaları, sanat üretme, sanatsal dili belirleme, sanatsal seçimler vb. konular üzerine inceleme yapılmak istendiğinde sanatla ilgilenen bireylere ya da sanatçılara kaynaklık edeceği düşünülmektedir. Sanatsal habitus, kapsamı çizilmiş ya da belirlenmiş bir grup üzerinde incelediğinde sanat ya da sanat eğitiminde kimlik, benlik, motivasyon, biyografik araştırmalar konularına yönelik göstergelerin okunmasına da destek olabilir.

Farkında olarak ya da olmadan edindiğimiz yaşantılar sanatla ilgili düşünsel yapımızı ve davranışlarımızı şekillendirmekte; yeteneklerimizin, bilgimizin oluşmasına veya gelişmesine katkı sunmaktadır. Bu oluşumu, sahip olduğumuz sermayeler ile sentezlemek, sanat alanındaki yerimizi belirlememize yardımcı olma noktasında işlev görecektir. Sanat alanındaki konumu belirleyiciliğine ek olarak öğretmenlik mesleğine bakışa ve meslek sürecindeki uygulamalara yansımaları bakımından habitusun rolü önemlidir. Sanat eğitimi bağlamında habitus üzerine düşünmenin, sanatsal kimliğin oluşumu ve eğitsel yaklaşımlara yönelik fikirler üretmek adına değerli bir teorik bakış açısı sunduğunu ifade edebiliriz.

Bu çalışmada, "Yükseköğretim Kurumları Bilimsel Araştırma ve Yayın Etiği Yönergesi"nde yer alan tüm kurallara uyulmuştur. Yönergenin ikinci bölümünde yer alan "Bilimsel Araştırma ve Yayın Etiğine Aykırı Eylemler"den hiçbiri gerçekleştirilmemiştir. 


\section{References}

Atkinson, D. (2002). Art in education: Identity and practice. New York, NY: Kluwer Academic Publishers.

Biçer Olgun, H. (2019). Çağdaş sanatın toplumsal inşası: Sanat eserinin değerinin sosyolojik oluşumu. Konya: Çizgi Kitabevi Yayınları.

Bourdieu, P. (1993). The field of cultural production, or: The economic world reversed. In R. Johnson (Ed.), The field of cultural production: Essays on art and literature (pp. 29-71). New York, NY: Columbia University Press.

Bourdieu, P. (2015). Ayrım: Beğeni yargısının toplumsal eleştirisi (D. F. Şannan \& A. G. Berkkurt, Çev.). Ankara: Heretik Yayınları.

Bourdieu, P. (2020). Sanatın kuralları: Yazınsal alanın oluşumu ve yapısı (N. K. Sevil, Çev.). İstanbul: Alfa Yayınları.

Bourdieu, P., \& Darbel, A. (2011). Sanat sevdası: Avrupa sanat müzeleri ve ziyaretçi kitlesi (S. Canbolat, Çev.). İstanbul: Metis Yayınları.

Danko, D. (2017). Sanat sosyolojisi (N. Z. Arslanoğlu, Çev.). Ankara: Hece Yayınları.

DiMaggio, P. (1982). Cultural capital and school success: The impact of status culture participation on the grades of U.S. high school students. American Sociological Review, 47(2), 189-201. doi:10.2307/2094962

Erinç, S. M. (2009). Sanat sosyolojisine giriş. Ankara: Ütopya Yayınevi.

Fazlıŏlu Akın, Z., \& Ece, Ö. (2014, Aralık). Türkiye'de sanat eğitimini (yeniden) düşünmek. https://www.iksv.org/i/content/230_1_SanatEgitimi_2014.pdf adresinden erişilmiştir.

Giddens, A., \& Sutton, P. W. (2016). Sosyoloji (M. Şenol, Çev.). İstanbul: Kırmızı Yayınları.

Grenfell, M., \& Hardy, C. (2003). Field manoeuvres: Bourdieu and the young British artists. Space and Culture, 6(1), 19-34. https://doi.org/10.1177/1206331202238960

Güvercin, G. (2017). Biyografik araştırmalar ve biyografik anlatı görüşmesi. F. N. Seggie \& Y. Bayyurt (Ed.), Nitel araştırma yöntem, teknik, analiz ve yaklaşımları içinde (s. 172-184). Ankara: Anı Yayıncılık.

Hardy, C. W. M. (2009). Bourdieu and the art of education: A socio-theoretical investigation of education, change and art (Doctoral Dissertation). Retrieved from https://ethos.bl.uk/ProcessOrderDetailsDirect.do?documentld=1\&thesisTitle=Bourdieu+and+the+art +of+education+\%3A+a+socio-

theoretical+investigation+of+education\%2C+change+and+art\&eprintld=550217

Hardy, C., \& Grenfell, M. (2006). When two fields collide: Bourdieu, education and a British artistic avant-garde. The International Journal of the Arts in Society: Annual Review, 1(2), 77-84. doi: 10.18848/1833-1866/CGP/v01i02/35451

Heinich, N. (2013). Sanat sosyolojisi (T. Arnas, Çev.). İstanbul: Bağlam Yayıncılık.

Huang, X. (2019). Understanding Bourdieu - cultural capital and habitus. Review of European Studies, 11(3), 45-49. doi:10.5539/res.v11n3p45

Johnson, R. (Ed.). (1993). The field of cultural production: Essays on art and literature. New York, NY: Columbia University Press.

Jourdain, A. \& Naulin, S. (2016). Pierre Bourdieu'nün kuramı ve sosyolojik kullanımları (Ö. Elitez, Çev.). İstanbul: İletişim Yayınları.

Karademir Hazır, I., \& Purhonen, S. (2017). Kültürel açılım, hepçillik ve seçkin sanatın düşüşü: TürkiyeAvrupa karşılaştırması. Ankara Üniversitesi ILEF Dergisi, 4(1), 29-58. doi: 10.24955/ilef.332367 
DEMIR YILMAZ \& ÇAKMAKOĞLU KURU - Çukurova Üniversitesi Eğitim Fakültesi Dergisi, 50(2), 2021, 677-697

Karademir Hazır, I., \& Warde, A. (2016). The cultural omnivore thesis: Methodological aspects of the debate. In L. Hanquinet \& M. Savage, (Eds.), Routledge international handbook of the sociology of art and culture (pp. 77-89). New York, NY: Routledge.

Karasar, N. (2017). Bilimsel araştırma yöntemi: Kavramlar-ilkeler-teknikler. Ankara: Nobel Akademik Yayıncilık.

Özsoy, V. (2007). Görsel sanatlar eğitimi: Resim-iş eğitiminin tarihsel ve düşünsel temelleri. Ankara: Gündüz Eğitim ve Yayıncılık.

Pautasso, M. (2013). Ten simple rules for writing a literature review. PLOS Computational Biology, 9(7), 1-4. https://doi.org/10.1371/journal.pcbi.1003149

Pera Müzesi. (t.y.). Zevk Meselesi. https://www.peramuzesi.org.tr/sergi/zevkmeselesi/1265 sayfasından erişilmiştir.

Sankır, H., \& Sankır, Ş. (2019). Öğrencilerin kariyer tercihi olarak sanata yönelmelerinde aile ve öğretmenlerin rolü: Güzel Sanatlar Lisesi örneği. Eğitim ve Bilim Dergisi, 44(199), 173-191. http://dx.doi.org/10.15390/EB.2019.7953

Schirato, T., \& Webb, J. (2004). Reading the visual. Australia: Allen \& Unwin.

Swartz, D. (2018). Kültür ve iktidar: Pierre Bourdieu'nün sosyolojisi (E. Gen, Çev.). İstanbul: Illetişim Yayınları.

Tezcan, M. (2011). Sanat sosyolojisine giriş. Ankara: Anı Yayıncılık.

Tezcan, M. (2016). Eğitim sosyolojisi. Ankara: Anı Yayıncılık.

Ulusoy, M. D. (2005). Sanatın sosyal sınırları. Ankara: Ütopya Yayınevi.

Webb, J., Schirato, T., \& Danaher, G. (2002). Understanding Bourdieu. Australia: Allen \& Unwin.

Wolff, J. (2000). Sanatın toplumsal üretimi (A. Demir, Çev.). İstanbul: Özne Yayınları.

Zolberg, V. L. (2013). Bir sanat sosyolojisi oluşturmak (B. O. Özbay, Çev.). İstanbul: Boğaziçi Üniversitesi Yayınevi. 